\title{
The construction of the 'we'-category: Political rhetoric in Soviet Estonia from June 1940 to July 1941
}

\author{
Andreas Ventsel \\ Department of Semiotics, University of Tartu \\ 78 Tiigi St. 50410 Tartu, Estonia \\ e-mail: andreas.ventsel@ut.ee
}

\begin{abstract}
The article asks, how one of the basic notions of cultural-political identity - we - is constructed in mass media, viz. which kind of semiotic and linguistic facilities are used in constructing a political unity. The approach used in this article is based on Lotman's semiotic theory of culture and on the analysis of pronouns in political texts, using Emil Benvenist's theory of deixis. Our case study concentrates on the years 1940-1941 which mark one of the most crucial periods in Estonian nearest history. The source material of the analysis consists of speeches of new political elite in power, all of which were published in major daily newspapers at the time. In outline, first year of soviet power in Estonia can be divided in two periods. First period would be from June 21 to "July elections" in 1940. In political rhetoric, new political elite tried to create a monolithic subject, the unity between themselves and people (people's will) by emphasizing activity and freedom of selfdetermination. Nevertheless, starting from "elections", especially from the period after "accepting" Soviet Republic of Estonia as a full member of Soviet Union, a transition of we-concept from an active subject to mere passive recipient can be detected. From that time on, people's will was envisaged as entirely determined by marxist-leninist ideology and "the Party".
\end{abstract}

The occupation of Estonia by the Soviet Union in June 1940 had a shocking effect on Estonian people. The former meanings that had constructed society and were crucial to human understanding were turned into being something with a minus sign and substituted with 
the Soviet ideological worldview. ${ }^{1}$ The following article analyses, therefore, how the ideology supporting the events of the 1940s found expression in the speeches of the new men of power. Among other things the analysis might be deemed interesting due to the fact that ideological construction of political reality is one of the constituting factors of human identity.

Defining 'ideology' has turned to a sort of glass bead game among scientists. Thus the well known author of several textbooks on political science Andrew Heywood defines ideology as a system of beliefs, the truth or falsity of which cannot be "proved in any scientific sense", but which nonetheless helps to structure our understanding of the world (Heywood 1990: 2). In the framework of this article I consider necessary to delimit ideology as a programmatic and rhetorical application of a grand philosophical system which agitates people to political action and can provide strategic guidelines for such activity (Hagopian 1978). Accordingly, ideology functions as a justification of political power, as a factor mobilizing the people and creates a mental order in the customary disorder of political life, providing the "ground principles"2 so to speak, by which the ideology perceives the surrounding world. Since politics had the subordinating role par excellence according to the self-reflection of the Soviet ideology, the political identity had also to shape the socio-cultural identity of human beings.

The concrete object of study is the category of we. Semantically the keywords used in the framework of this article are the ones established in the political rhetoric such as the will of the people, the people etc., $\mathrm{i}$. e. these referring to on whose behalf it is being spoken in politics.

The analyzed material is composed of the largest daily newspapers Päevaleht (issues from 1938, 1939 and 1940) and Rahva Hääl (issues

The determining factors of the public ideological discourse in the pre-War Republic of Estonia (1918-1940) were the valuing of fatherland and family, the participation in patriotic unions, the celebration of national anniversaries. The sacral status was ascribed to the ancient time and Lembitu, Päts and Jakobson, Laidoner and the war of independence, patriotic poetry and folklore, which all together shaped the essence of the national whole.

2 "The Marxist-Leninist theory is the science of societal development, the science of workers' movement, the science of proletarian revolution, the science of building the communist society" (The History of the Union-wide Communist (bolshevist) Party: A Crash-Course — Lühikursus 1951 [1938]: 321). 
from 1940 to 1941). ${ }^{3}$ The essential part of the sources is formed of speeches of the politicians published in the press and of the editorials of the daily newspapers. Choosing media as the empirical object of study can be justified mainly by the fact that the media (especially the editions that cover daily news) reflects the worldview, ideology and value-orientations of a community (Lauk, Maimik 1998: 80).

\section{The two dimensions of the we-category}

As indicated above the political discourse is in this article approached mainly through the speeches of politicians. For many scientists the verbal communication is the most important constituent of discourse (Dijk 1998). The importance of political rhetoric is also expressed in the fact that it is through that that the official political position and intellectual framework is fixed - a framework that is the basis not only for describing and cognizing the surrounding world but also for altering it (Hertzler 1965: 3-4).

The discourse analysis approach emphasizes that the discourses are inseparable from power - their impersonal all-encompassing power to construct reality, but also the power exercised by subjects in (re)producing meanings.

The notion of "discourse", as developed in some contemporary approaches to political analysis, has its distant roots in what can be called the transcendental turn in modern philosophy - i. e. a type of analysis primarily addressed not to facts but to their conditions of possibility. (Laclau 1993: 431)

At the same time this relationship between power and discourse should not be understood in the traditional framework for conceptualizing power and politics in which power is seen in terms of legal means (and ontologically as an "object" or "thing") to protect private property in the name of public good (the liberal tradition from John Locke to John Rawls). The relationship between power and politics has also been described in terms of economic competition for votes in order to gain power (Joseph Shumpeter) and politics has been

3 After the coup in 1940 the newspaper Päevaleht was closed down. The newspaper Rahva Hääl [literally People's Voice] that was founded in June 1940 instead of newspaper Uus Eesti [literally New Estonia] formed one of the main official voices of the Communist Party of Estonia. 
connected with interactions governed by public ethical norms (Jürgen Habermas). These approaches however leave unanswered the main question: how is a power relation established?

The focus of studying political power moves away from the sovereign forms of power like state or administrative apparatuses and the hitherto systematically concealed forms of power enter the center of attention in the social sciences. In this framework politics can be conceptualised as "a practice of creation, reproduction and transformation of social relations" (Laclau, Mouffe 1985: 153) that can always be seen as an expression of the powers of discourse. One of the possibilities for constructing a power relation is through the use of deictics.

It is true that the tradition of describing deixis has a long history reaching back to the Stoics. But since Karl Bühler's Sprachtheorie (1934) the deixis has a well-established place in scientific linguistic studies. The deixis analysis has also extended its theoretical basis: devices for analysis have been borrowed from analytic philosophy (e. g., Kripke 1990; Evans 1985, etc.), semiotics (e. g., Greimas, Courtes 1993 [1978]) as well as from cognitive science (e.g., Lyons 1977; Fillmore 1982; Brown, Yule 1983). While other elements of language in political discourse have attracted attention well enough ${ }^{4}$ the role of deixis in constructing power relations has largely been underestimated (cf. Weintraub 1989). The following could be regarded as a small contribution to filling that gap by using a concrete empirical material.

The deixis, as is well known, encodes in the utterances the person of the speaker, his/her subjectivity and spatiotemporal context and it is formed of corresponding orientational vocabulary and grammatical means. The deixis's rules of use enable the addressee to decode the utterance according to its context and to determine the extra-linguistic factors eliciting the content.

In the case of we the $I$ and you form a unified subject that at a certain phase of the speech feels, thinks, speaks and acts unitedly but can be changed again latter - expanded, disintegrated, generalized or replaced. But, as Émile Benveniste explains the we is a very special kind of union that is based on the non-equivalence of the members: the we does not consist in a mechanical aggregation of different $I$-s but in the we there is always a dominant $I$ (the subject of the utterance) and this $I$ due to its transcendence subjects to itself a not- $I$ which

4 E. g., metaphor (see Lakoff 1992; 1996); lexis (see Lasswell et al. 1949, etc). 
means that only through stepping out of itself it creates that we and thus determines the not-I (Benveniste 1966: 236-237). There are few words that are so ideologically and socially charged as the pronoun we. Through speaker's emphases the social relations, statuses, power and ideology are expressed through it and the addressee manipulated (Dijk 1998: 201-203). By analyzing the use of the personal pronouns in the political discourse (like the we in the speeches of the politicians) it is possible to study the rhetoric mechanism by which the membership of the in-group signified, the distancing it from its outgroup or is marked, and the denigration of the out-group, the activism or passivity of the social agents and many other functions of the speech. It would be even more apt to say that the speaker constructs, creates the subject present in the utterance, the one on whose behalf he/she speaks.

Conceived this way the subject's characteristics can be expanded to larger imaginary communitarian wholes. Thus for instance the social classes are subjects, whose unity is constituted by interests that are determined by their position in the relations of production. Similarly a nation is an integral subject that is united by an identity based on language, culture, religion, history or other factors. The concept of we $(u s)$ that is accompanied by an opposition with them can be considered semiotically as the main characteristic of culture. Therefore, this opposition determines and delimits the type of the relation between culture's self-description (organized space) and other culture (unorganized space). Hence for every culture corresponds a type of its "chaos" that is not necessarily homogenous and always identical with itself but consist in an active human creation as the domain of the cultural organization (Ivanov et al. 1998: 33)

According to Juri Lotman the national-cultural specificity is at the primary stage grasped by outlanders (Lotman 1999: 45). Thus it is understandable that for instance at the ideational bearers of the first phase of the Estonian national awakening were mainly intellectuals of German origin. ${ }^{5}$ We have here rather a question: who are they

The "national awakening" is a stipulative term coined in the Estonian historical literature in the first decades of the 20th century. It refers to the period when against the background of economic and social change in the second half of the 19th century the acknowledgement of nationality began in the Estonian literary communication and the awakening of the national self-consciousness and national movement started to emerge. 
(Estonians as a social group that has not yet uniformly determined identity) that are not us (Germans as a nation with full-fledged identity). At the next phase when a culture that had thus far been only an object of description, reaches at the level of self-description, it takes "an exterior viewpoint towards itself and describes itself as unique" (Lotman 1999: 46). Estonians are counted in the so-called "nations without history". Therefore the first ideologies of Estonianism relied on ethnic traditions and folkloric myths. In constructing the national narrative and history the experiences of other nations were followed and linked with ideas popular at the time (Annus 2000: 89). A special role in the shaping of the spiritual life (as for all of the Eastern-European small nations) was played by the ideas of Johan Gottfried Herder (Undusk 1995: 581). A positive and integral selfidentification thus answers to the question: who are we? And through simultaneously opposing itself to the other - the not-we (for example to other nations) - the nation or class at the same time identifies itself negatively: we are not what are the others. At this phase an ideology is formed in which the self is conceived as sovereign.

The concept of the subject correlates to that of the object. The drive to self-organization depends on the mode of the relations in society. The mode of these relations determines weather the human being cognizes itself as the subject or object of the creation of culture. In this article the word we in addition to its meaning as a deictic pronoun refers exactly to such a category defined as a unified whole.

Two aspects of the we-category will be focused in the analysis:

(1) How it was constructed as a subject-object relation in the Soviet propaganda.

(a) During the span from the "coup of June" to the July "elections". 6

(b) The period from July 1940 to the German occupation in July 1941.

(2) How was the "we" positioned deictically in texts?

6 In July 14-15 1940, general elections of the State's Council were held which was a spectacle conducted according to the directives from Moscow. The clique that had carried on the "Coup of June" aggregated around the electoral block of Estonia's Working People's Union (EWPU), who, having the position of power, cancelled out any nomination of candidates from the opposition. As a result the EWPU got $92.8 \%$ of votes from the "election". 


\section{Historical introduction}

June 1940 Estonia, Latvia and Lithuania were occupied by the Soviet troops. In the public-political discourse it was presented as the institution of the power of the people. In august the 6th Estonian Republic was incorporated into the Soviet Union, which, in turn, was called "joining the USSR on voluntary basis".

In actuality, the Soviet Union had already on the 23rd of August 1939 entered into pact with the German Reich, the secret protocols of which established the Baltic States as part of the Soviet's sphere of influence. In September the same year the Soviet Union began to realize its aggressive foreign politics. On the 28th of September in Moscow under the pressure of the Soviet Union the contract of mutual aid was signed with Estonia, by the terms of which Estonia had to allow the building of the military basis of the Red Army to Saaremaa, Hiiumaa and Paldiski. In the early summer of 1940, when the whole world's attention was focused on the successful action of Wehrmacht in France, the Soviet government decided to realize conclusively the agreements of the secret protocols of the Hitler-Stalin pact. On the 16th of June 1940 the Soviet Union delivered an ultimatum to Estonia, accusing Estonia of military cooperation with Latvia and Lithuania, which supposedly threatened the national security of the Soviet Union. A response to the ultimatum which stipulated the establishment of a new government and a free access to the additional military forces of the Soviet Union was to be given on the same day. In case of refusal the units of the Red Army were to move to Estonia by force. The government of Estonia, considering the political situation of that day Europe, decided to accept the terms of the ultimatum and on 17th to 18th of June the Soviet troops occupied the Republic of Estonia. On the demands of Moscow, a new and clearly Soviet-oriented government was appointed, the head of which became Johannes VaresBarbarus. The Coup of June was accomplished. 


\subsection{The deictic constitution of the we-category in the speeches of the politicians}

Johannes Vares-Barbarus begins his first speech in the 25th of June issue of the Rahva Häal as follows: ${ }^{7}$

A Miracle has happened $-w e^{8}$ have won. Our day of victory has become the day of freedom. We all are patriots and love country and people. (VaresBarbarus 1940a)

Here a question arises: whom does Vares-Barbarus mean by we? Should the addressee of the communication be distinguished from that we on whose behalf it was spoken? And what do the words "we all" mean in the last sentence? The speech by Vares-Barbarus allows to claim that at first by the "we all" it was meant a part of a whole. Further in his speech Vares-Barbarus stresses the conclusiveness of the events of June the 22nd but adds that even

the most magnanimous of wills and human capacities have limits, we already have done more but to gain even more it takes organized work and pains, therefore my hope is on the assistance of all the citizens. (Vares-Barbarus 1940a)

Hence it is clear that the we of the addresser does not indicate speaking on behalf of the whole people because the last part of the sentence ("the assistance of all the citizens") allows conceiving people as something external. The we of the addressee and the we of the speaker (the speaker and the other communists on whose behalf it was spoken) exist separately in this speech. This separation is also detectable in the pre-election speech of Hans Kruus on the July 10th issue of the Rahva Häal: ${ }^{9}$

All the votes to Estonia's Working People's Union. No votes to the adversaries of our demands and platforms. [...] Every human being possessing even

\footnotetext{
7 Johannes Vares-Barbarus was the prime minister of the "people's government" (the Moscow-minded government) since June 1940. After the incorporation of the Republic of Estonia to the Soviet Union in august 1940 Vares-Barbarus became the chairman of the Presidium of the Supreme Council of the Estonian SSR.

Here and hereafter all the italics are added by me $-A$. $V$.

9 Hans Kruus was the minister of education and the deputy of the prime minister of the "people's government".
} 
the least of attentiveness and knowledge has been able to witness the great changes that have taken place in our state and social life after the June 21st. (Kruus 1940a) $)^{10}$

The gap between the addresser and the addressee of the speech is still to be overcome. The intra-textual opposition between the parties of the communication disappears during the period following the "election". Vares-Barbarus confirms in a speech on July the 15th after the triumphant "electoral" victory ( $92.8 \%$ of votes to EWPU):

My esteemed fellow strugglers and comrades! Chinese walls of different kinds have been torn down between us [meie]. Torn down is the wall between us and the Soviet peoples. ${ }^{11}$ Secondly that Chinese wall between the people and the ruler collapsed with the accompanying cheers of the working people and without the Jericho horns. [...] No force can hold $u s$ back from giving hand to each other for common struggle for freedom. There is no step backward. The die is cast! (Vares-Barbarus 1940b)

In the second sentence Barbarus specifies the position of the wecategory through its belonging to a larger semantic whole - the socalled "family of the Soviet peoples". From the point of view of the interior unity the most important aspect is the disappearance of the gap between the ruler and the people in the third sentence. A unified subject is created in the utterance. The speaker identifies the public or people with itself or as Benveniste would put it: the $I$ subjects the non$I$ so that both now belong semantically to the same grammatical and semantic whole. At the same time the grandness of the break is emphasized by the figure of the Chinese wall and the attitude towards the preceding period as something conclusively past and overcome is marked by the deictic that.

10 In Estonian there is certain ambivalence in the word "meie" in this quotation that has some rhetorical charge: it means both the normal meaning "our" and grammatically it could also mean the more technical construction "of the we" where "we" is seen as a subject not merely a demonstrative pronoun. The grammatical reason for this is that the nominative and the possessive case for the word "meie" (we) are identical.

11 Here again the rhetorical charge derives from the grammatical peculiarities of Estonian language: the phrase can semantically be read both as "between $u s$ and the Soviet peoples" as well as "between the we and the Soviet peoples". 
2.2. The formation of the subjectivity of the we-category in the speeches by the politicians

The period from the coup of June to the election in July can be seen as the first phase of the formation of the subjectivity of the we-category. During that period a transition took place from the addresser-addressee opposition (expressed in the separation between them) to their unity, i e the speakers (local communists) spoke on behalf of both themselves and the spoken-to. In the first speech by Vares-Barbarus the subject is above all the we of the speaker, i e the local communists who had carried out the coup. In addition it implies ascribing activism and causality. Those who were addressed were passive receivers. They did not have their own face yet in the framework of the new ideological paradigm, in other words their identity (as a certain system of meanings) was "out of joint". But in the following speeches there is a traceable development towards eliminating the opposition between addresser and the addressee and the elaboration of soviet identity unifying both counterparts. The speaker turns into an anonymous medium at the expression of the will of the people. In the speeches a category of we (the people) was constructed that was simultaneously the speaker and the spoken-to and that expressed the will of itself: "the real will of the people has emerged in the elections" (Säre 1940a). ${ }^{12}$

\section{The changes in the we-category from the July "election" in 1940 to July 1941}

On July 14-15, an "election" was held according to the directives from Moscow in order to "legitimate" the soviet coup in Estonia. After the July "election" the nascent State's Council decided to change the name of the Republic of Estonia into Estonian Soviet Socialist Republic and to submit an application for ESSR's accession to the Soviet Union. On the 6th of August 1940 in Moscow the Supreme Council of the Soviet Union decided to fulfill the request of the Estonian SSR. The annexation in accordance with the scenario of Moscow had been accomplished completely.

12 Karl Säre was the first Secretary of the Central Committee of the Estonian Communist Party in 1940-1941. 
In what follows I will analyze the ways in which the construction of the we-category in the speeches of the statesmen was altered in the new situation after the parliament elections. The afore presented speech by Vares-Barbarus on the July 15 (Vares-Barbarus 1940b) could be held as a communicational turning point in the parties' formation of the we-category. For the first time in any statesman's speech we can witness the greetings addressed to the Red Army, the Communist Party of the Soviet Union and their representatives Stalin for most of the occasions. ${ }^{13}$ The canonical sequence of greetings, so to speak, can for the first time be detected at the end of the speech by Estonian Communist Party's representative Karl Säre on the July 16 issue of the Rahva Hääl :

Long live the friendship between Estonia and the powerful Soviet Union; Long live the heroic and undefeatable Red Army; Long live the tried out leader for the Estonian proletariat and for the entire working people: the Estonian Communist Party; Long live our teacher, friend and leader, the great Stalin! (Säre 1940a)

The purpose of the obligatory greeting addresses is not to contact or enter a dialogue with the immediate audience of the addresser, but the communication with the "third" party. According to Mikhail Bakhtin there is a third party in every dialogue who does not formally participate in the process, but in relation to whom the real communicants order their positions: for instance: God's judgment, the eye of history, consciousness etc. (Bakhtin 1979: 149-150). In the Soviet situation the third party is formed of the Communist Party headed by Stalin. In the analyzed actual situations of communication between the local statesmen and the public, Stalin as a third party concealed in the text becomes the real addressee of the message. It is precisely the latter in relation to whom the addresser may not be in error when building up the discourse. The speeches passed a strict Moscow-minded censorship through which even the least of deviations from the speech canon approved by Moscow were eliminated. If we consider the tradition of Estonian political rhetoric that had preceded the Soviet Occupation it can be said that the speeches suffered a pragmatic deficiency for the local audience. Of no small importance in this connection is the fact

13 In the first issue of the Rahva Hääl (June 22,1940) there was a coverage of the people's reaction that found its expression in a "powerful hurricane of greetings to the Red Army, to comrades Stalin, Molotov, Vorošilov, Timošenko!" 
that there was no activeness on the proper-name level among the local party board.

Functionally the greetings had a role of constituting the hierarchical, centralized structure characteristic to the soviet ideology. In view of this feature the whole spiritual culture is describable as a pyramid ${ }^{14}$ on whose top lye the politico-ideological values. As Lenin have said: "We have now become an organized party, and that means creating the power, turning the authority of ideas into the authority of power, the subjugation of the lower instances of the party to the higher ones" (Lenin 1946: 339). And this alters significantly the deictic use of the we-category. The changes that had taken place in the speeches of the politicians did not involve exclusively the formal greetings directed to the "third party". In a speech by Vares-Barbarus on the 1st of August the unity of the we-category is first emphasized:

We shattered the old retrograde regime. We declared the land the property of the people, we declared the industry nationalized to end the exploitation of the human being by a human being. From now on the workers, the peasants and the working intelligentsia are the plenipotentiary masters of the land. (VaresBarbarus 1940c)

The increasingly battleful emphasizing of the coup sets the former power (that has been overcome at the now-point) as one that is old and retrograde behind the back of the we-subject on the linear time axis, at the same time indicating the inhumanity of old regime (the end of the exploitation of the human being). The structural form characteristic to the Soviet ideology is filled with the purely ideological content - the power of the proletariat, the nationalization, the end of exploitation. And in the last sentence the result of the activeness of the we is presented. But it is important to notice that in here this activeness determines the whole causal chain of the events. The nowdeictic signifying the substitution of power is like a zero-point marking the beginning of time, from which the position of the subject

\footnotetext{
14 This centralized hierarchy did not show itself not only in the authority of the central party over the local ones but was also expressed in the entire socioclutural environment. Thus Kaginski identifies as the main characteristic of the soviet space the strict structurality and the dependence of that structure on the vertical, hierarchical and power-related dominants (Kaginski 2001: 157). A sharp hierarcy among nations showed itself in the speeches of the politicans after the famous toast in honor of the Russian people by Stalin after the Second World War.
} 
is defined. In fact it means the positioning of the we to an entirely new notion of time and history. Having their starting point in the German romanticism and Herderian conception of culture in which the idea of history had become the idea of the nation and its historically unique self-fulfillment or an idea of national culture is what distinguishes the Estonian notion of history from that of the Marxist one. In the Marxist social theory the culture is reduced to the superstructure of the economic formation and is dependent on the latter. The development of the economic formation and hence the development of history depends on the dialectic of the development of the mode of production constituting the social organization. Such determinism however refers to a world history or general history which cancels out the independence of someone's own history, so to speak. The modification is clearly present in the speech by the first secretary of the Central Committee of the Estonian Communist Party K. Säre who explicitly refers to the Stalinist constitution as a great sign-post in the world history: "the III five-year plan in which the world-historical mission will be accomplished: the transition from socialism to communism" (Säre 1940b). But in the subsequent speech by Vares-Barbarus the integral and active we-category moves into a new position:

We have an enormous work ahead of us that has already been done by you. [...] Under the sun of the Stalinist constitution we bring the country to prosperity ${ }^{16}$. [...]Our sun rises from the east now, the west remains behind our back as a cardinal point from which nothing rises. (Vares-Barbarus 1940c)

In the first sentence the we-category is opposed by a new case of second person plural - you. And at the same time changes the position of the we-category in relation to the political reality pictured in the text. A hierarchy forms among the agents presented in the utterance - a hierarchy in which the speaking we (a unitary „people“ created by the Estonian politicians) is underneath the speech and the enormousness of our "undone work" and the indication to the deficiency of the speaking subject (the Estonian nation) increases the

15 In a special study on this issue the author has never observed any attempt in the speeches by politicians of the Estonian Republic to connect the Estonians to the world history and messianic world-cognition.

16 The tying of the Stalinist constitution with the symbol of the sun as a life enabling source found its expression also in the coat of arms of the Soviet Estonia (Rahva Hääl, October 10, 1940). 
power position of the you-category even more. The spatial and verbdeictics (behind, rise) define the we-category's socio-cultural belonging to the locus of the East (the Soviet Russia). The wecategory that had previously signified the unity between the addresser and the addressee and had become an active subject (Vares-Barbarus 1940b) looses in this speech its sovereignty and also its subjectity. The possibility of the we is based on and justified by an other - in the given speech by the sun of the Stalinist constitution. I shall add some other examples of the transformation of the we-category in the speeches from the active subject to object. Hans Kruus says in his speech on the 9th of August 1940: "The Stalinist constitution gives an irrefutable basis and firm framework" (Kruus 1940b). By the Stalinist constitution it is meant here a principle enabling the "right" being and at the same time the constituting condition for reality. That is corroborated by the successive utterance of Kruus: "The Stalin's constitution shall be a document that testifies that what is accomplished in the USSR can also be accomplished completely in other countries." And finally: "We have no doubt that the new order will bring principled and actual growth of and unprecedented human dignity". ${ }^{17}$ Basically the same point is made by Säre in his speech on the anniversary of the Great Socialist October Revolution on the 5th of November 1940:

Through self-denying struggle the Russian proletariat has gained the place of the people's leader. [...] The proletariat is led by the brave and farseeing bolshevist party $[\ldots]$ as has been said by comrade Stalin $[\ldots]$ and all this is corroborated by clear facts. (Säre 1940b)

Although the conclusiveness of the coup of June is apparent in the earlier speeches by Vares-Barbarus and other party figures, the previously described period of the formation of the we-category is concentrated on the abolishment and "destruction" of the old regime. Thus the activity is meant rather as a negative activeness. ${ }^{18}$

17 I add here a quotation from a brochure characterizing the Soviet Estonia (Sovetskaja Estonija): "The heroic warriors of the Red Army were not just seen as the representatives of the big and friendly Soviet Union by the Estonian people but also as the bearers of a higher socialist culture, representatives of the new order" (Jefimov 1940: 43).

18 Jaan Undusk has observed similar tendencies in the history writing discourse of the Soviet Estonia, characterizing the ways Estonians were pictured as a "only 
The cognition enabling the new reality arrives at the speeches only after the "joining" the Soviet Union and is connected to the party's subordinating role towards the possibilities of cognition. The activity of the we is reduced now to the receiving and mediating of the objectifying activity of the new subject of the speech - the party or rather Stalin. The transition from the activeness to passivity, from the unconditioned to the conditioned takes place. Thus the we that had previously attained its unity in the utterance looses its independence, turning into an object for the party, and especially for Stalin to whom exclusively the position to be a subject was reserved in the public Soviet political discourse at that time. Stalin was the one who gave meaning to the we or "the soviet people" in the speeches. Behind this there was of course a simple Realpolitik: from the "soviet people" were excluded those who disagreed with the politics of Stalin. The Stalinist slogan "Cadres will decide everything" and the accompanying "self-criticism of the party" are actually one of the ideological concealments of this "game of exclusion". Thus it can be said that the "soviet people" created by Stalin was identical to the "we" that was created by his "I". In consequence it can be said that the soviet ideology resembles to the cultural type (if we understand in this context ideology as synonymous to culture) that was characterized by Lotman as an aggregation of texts that opposes to cultural type that creates the aggregation of texts (Lotman, Uspenski 1994: 245). In this cultural type the content of the culture is pre-given from the standpoint of the self-understanding of this culture; it consists of prescriptive sum of the "right" texts: in the Soviet ideology they were formed of the works of the Marxist-Leninist classics and in the Stalinist era mostly the works of Stalin himself. ${ }^{19}$ In such a cultural type the subject of the speech as a creator of the reality (content) in the utterance has only relative value. Everything new is actually predictable and known to the knowers - the real subjects (Marx, Engels, Lenin, Stalin). Paraphrasing Benveniste it could be said that the $I$

then" and "already at that time" syndromes that characterized Estonians as hopelessly behindhand and supressed compared to Russians (Undusk 2003: 53-54).

19 In fact the chrestomatic canonization of Marx's and Lenin's works depended on Stalin's concrete needs and it was not uniform and invariable (Vaiskopf 2002). 
subjected the non-I completely or the $I$ created the we completely according to its arbitrary will. ${ }^{20,21}$

\section{References}

Annus, Epp 2000. Kiigelaual mineviku ja tuleviku vahel: rahvuslikust mütoloogiast. Looming 1: 88-99.

Bakhtin, Mikhail 1979 = Бахтин, Михаил. Эстетика словесного творчества. Москва: Искусство.

Benveniste, Émile 1966. Problèmes de linguistique générale I. Paris: Gallimard.

Brown, Gillian; Yule, George 1983. Discourse Analysis. Cambridge: Cambridge University Press.

Dijk, Teun van 1998. Ideology: A Multidisciplinary Approach. London: Sage Publication.

Evans, Gareth 1985. Understandings Demonstratives. In: Evans, Gareth, Collected Papers. Oxford: Clarendon Press, 291-321.

Fillmore, Charles F. 1982. Towards a descriptive framework for spatial deixis. In: Jarvella, Robert J.; Klein, Wolfgang (eds.), Speech, Place, and Action: Studies in Deixis and Related Topics. Chichester: John Wiley and Sons, 31-59.

Hagopian, Mark N. 1987. Regimes, Movements and Ideologies: A Comparative Introduction to Political Science. London: Longman.

Heywood, Andrew 1990. Political Ideologies: An Introduction. New York: St. Martin's Press.

Greimas, Algridas J.; Courtes, Joseph 1993. Semiotique - Dictionnaire raisonne de la theorie du langage. Paris: Hachette Superieur.

Hertzler, John 1965. A Sociology of Language. New York: Random House.

Ivanov, Vyacheslav; Toporov, Vladimir; Pjatigorskij, Aleksander; Lotman, Juri; Uspenskij, Boris 1998. Theses on the semiotic study of cultures (as applied to the Slavic texts). Tartu Semiotics Library 1: 33-60.

Jefimov, Mihhail $1940=$ Ефимов, Михаил. Советская Эстония. Таллин: ОГИС.

Kaginski, Vladimir 2001 = Кагинский, Владимир. Культурный ландшафт и советское обитаемое пространство. Москва: Новое литературное обозрение.

Kripke, Saul 1990 [1977]. Speakers`s reference and semantic reference. In: Martinich, Aloysios P. (ed.), The Philosophy of Language. 2nd ed. New York: Oxford University Press, 248-267.

20 In a strictly hierarhized society the Party was not a unified subject either despite its being sometimes presented as one in texts. The Party was led by Stalin, God's (Lenin's) vicar on earth who exclusively possesed an $I$.

21 The article has been written with the support of Estonian Science Foundation grant ETF6484 "Nomination and Anonymity in the Culture". 
Laclau, Ernesto; Mouffe, Chantal 1985. Hegemony and Socialist Strategy, London: Verso.

Laclau, Ernesto 1993. Discourse. In: Goodin, Robert E.; Pettit, Philip (eds.), A Companion to Contemporary Political Philosophy. Oxford: Blackwell, 431437.

Lakoff, George 1992. The contemporary theory of metaphor. In: Ortony, Andrew (ed.), Metaphor and Thought (2nd edition). Cambridge: Cambridge University Press, 202-251.

- 1996. Moral Politics. Chicago: University of Chicago Press.

Lasswell, Harold; Leites, Nathan; Fadner, Raymond; Goldsen, Joseph M.; Grey, Alan; Janis, Irving L.; Kaplan, Abraham; Mintz, Alexander; Sola Pool, I. De; Yakobson, Sergius; Kaplan, David; Stewart, George W. 1949. Language of Politics: Studies in Quantitative Semantics. New York: George W. Stewart.

Lauk, Epp.; Maimik, Peeter 1998. Ajakirjanduslugu on osa rahvuskultuurist. In: Lõhmus, Maarja (ed.), Kultuur ja analüüs. Tartu: Tartu Ülikooli Kirjastus, 76-90.

Lenin, Vladimir 1946 = Ленин, Владимир. Сочинения, т. 5. Ленинград: Политиздат.

Lotman, Juri 1999. Kultuur kui subjekt ja iseenese objekt. In: Lotman, Juri, Semiosfäärist. Tartu: Vagabund, 37-53.

Lotman, Juri; Uspenskij, Boris 1994 = Лотман, Ю. М.; Успенский, Б. А. Роль дуальных моделей в динамике русской культуры. In: Успенский, Б. М. Избранные труды, І. Москва: Гнозис, 219-255.

Lühikursus 1951 [1938] = Üleliidulise kommunistliku (bolševike) partei ajalugu: Lühikursus. Tallinn: Eesti Riiklik Kirjastus.

Lyons, John 1977. Semantics. Vol. 2. Cambridge: Cambridge University Press.

Ots, Loone 1998. Kultuuri uurimine ja kultuuri õpetamine. In: Lõhmus, Maarja (ed.), Kultuur ja analüüs. Tartu: Tartu Ülikooli Kirjastus, 64-75.

Undusk, Jaan 1995. Hammani ja Herderi vaim eesti kirjanduse esindajana: sünekdohhi printsiip. Keel ja Kirjandus 9: 577-585; 10: 669-677; 11: 746756.

Undusk, Jaan 2003. Retooriline suund Eesti nõukogude ajaloo kirjutuses. In: Krikmann, Arvo; Olesk, Sirje (eds.), Võim ja kultuur. Tartu: Ilmamaa, 41-69.

Vaiskopf, Mihhail 2002 = Вайскопф, Михаил. Писатель Сталин. Москва: Новое Литературное Обозрение.

Weintraub, Walter 1998. Verbal Behavior in Everyday Life. New York: Springer.

\section{The analysed speeches}

Kruus, Hans $1940 \mathrm{~b}=$ Rahva Hääl 10.07.1940. Valimiste kõne.

Kruus, Hans 1940d = Rahva Hääl 9.08.1940. Kõne Eesti NSV vastuvõtmise puhul Nõukogude Liitu.

Stalin, Jossif 1945 = Rahva Hääl 26. 05. 1945. Toost suurele vene rahvale

Säre, Karl 1940a = Rahva Hääl 16.07.1940. Valimiste kõne.

Säre, Karl 1940b = Rahva Hääl 7.11.1940. Revolutsiooni aastapäeva kõne. 
Vares-Barbarus, Johannes 1940a = Rahva Hääl 25.06.1940. Kõne uue valitsuse ametisse astumise puhul.

Vares-Barbarus, Johannes 1940b = Rahva Hääl 15.07.1940. Valimiste kõne.

Vares-Barbarus, Johannes 1940c = Rahva Hääl 1.08.1940. Kõne töötavale rahvale.

\section{Конструирование категории «мы»: советская политическая риторика в Эстонии с июня 1940 до июля 1941}

Одним из поворотных пунктов в новой истории Эстонии были 19401941 гг. В статье автор ищет ответ на вопрос: каким образом было сконструировано в публичных СМИ понятие «мы» - одна из основных категорий культурно-политического идентитета. В качестве источников используются речи политической элиты (Варес-Барбарус, Лауристин, Круус и мн. др.), опубликованных в основных газетах того времени. Начальное время советской власти в Эстонии можно разделить на два периода: первый условно датируется с 21 июня до «июльских выборов» в 1940 году, когда в политической риторике стремились к созданию единого монолитного субъекта и единство народа и власти описывали в категориях активности, творчества и свободы. Но начиная с «приема» Эстонской Советской Республики в Советский Союз 6 августа 1940 года в самоописании «мы» произошел существенный сдвиг. Местный «народ» был отодвинут на роль пассивного получателя, его подчинили марксистско-ленинской идеологии, диктату и воле Сталина и его партии. Для этого были использованы разные риторические средства — дейктики, пассивные формы глагола и т.п.

\section{"Meie" kategooria konstrueerimine: nõukogude poliitiline retoorika Eestis juunist 1940 kuni juulini 1941}

Aastad 1940-1941 märgivad üht pöördelisemat perioodi Eesti lähiajaloos. Artiklis otsib autor vastust küsimusele: kuidas kultuurilis-poliitilise identiteedi üks põhikategooriaid "meie" konstrueeriti avalikus meedias. Uuritakse, milliseid semiootilisi vahendeid kasutati niisuguse poliitilise ühtsuse konstrueerimisel tekstides. Käesolevas artiklis lähenetakse püstitatud ülesandele Lotmani kultuurisemiootikast lähtuvalt ja asesõnade analüüsi kaudu. Analüüsi allikmaterjalidena kasutatakse poliitilise eliidi (Vares-Barbarus, Lauristin, Kruus jpt.) kõnesid, mis avaldati peamistes tolleaegsetes meediaväljaannetes. Nõukogude võimu algusaega Eestis 
võib jagada kaheks perioodiks. Esimest perioodi võiks tinglikult dateerida 21. juunist kuni "juulivalimisteni" 1940. aastal, kus poliitilises retoorikas üritati luua ühtne monoliitne subjekt ning ühtsust võimu ja rahva vahel kirjeldati kõnedes aktiivsuse, loovuse ja vabaduse kategooriates. Kuid alates Eesti Nõukogude Vabariigi "vastuvõtmisest" Nõukogude Liitu 6. augustil 1940. aastal toimus "meie" enesekirjelduses oluline nihe. Kohalik "rahvas" oli kõnedes taandatud passiivse vastuvõtja rolli, kus ta allutati marksistlik-leninlik ideoloogiale, Stalini ja tema Partei diktaadile ja tahtele. Selleks kasutati erinevaid retoorilisi (deiktikud, tegusõnade passiivsed vormid jne) ja semiootilisi vahendeid. 
